\title{
TRIUNE AGENCY, EAST AND WEST: UNCREATED ENERGIES OR CREATED EFFECTS?
}

\author{
ADONIS VIDU* \\ Gordon-Conwell Theological Seminary
}

\begin{abstract}
The present paper situates the Western and Eastern models of divine agency within their respective ontological frameworks. I show how the Western conception of divine agency as the production of 'created effects' is rooted in a particular understanding of the relationship between transcendence and immanence, but also in a trinitarian ontology which understands God as pure actuality. On the other hand, the Eastern understanding of divine agency through the conceptuality of uncreated energies is similarly rooted in the real distinction between God's nature and energies. Without trying to critique the Eastern model, I demonstrate one particular strength of the Western approach, namely its ability to distinguish between divine actions, which are inseparable, and divine missions, which are proper to the triune persons. Such a distinction enables us to affirm both the inseparability of triune operations, as well as the possibility of relations to distinct triune persons.
\end{abstract}

KEYWORDS: Created Effects, Uncreated Energies, Deification, Divine Action, Simplicity, Trinity

The question of what it means for the transcendent God to act in the world has vexed theologians and philosophers from all Christian traditions. There are many dimensions of this issue that make it particularly difficult, only a few of which shall be named. First, affirmation of the ontological difference between God and creation makes it difficult to imagine what it might mean for this God to act in the world. The problem is not inspired by Gnostic loyalties, as much as it is a question that, were such a God to act in the world, would a human observer have access to these actions precisely as divine, given that divinity transcends the created order? Second, and also related to divine transcendence, there is the difficulty of reconciling the simplicity and immutability of God with the fact that actions within a temporal world seem to imply both composition and mutability. In other words, it is difficult to understand how a simple and unchanging God might personally relate to a changing and temporal creation, whilst preserving its character and auton-

* ADONIS VIDU (PhD 2003, University of Nottingham) is Professor of Theology at Gordon-Conwell Theological Seminary. Email: avidu@gordonconwell.edu. 
omy. Finally, there is a difficulty that results from the law-governed reality of the created world. This is the question of so-called special divine action, namely how God's action in the world, should there be such a thing, relates to the ordered and law-governed character of the physical world.

The themes of this volume, the deification of the creature and the beatific vision, hint at many of the difficulties above. A thoughtful account of deification, as an act of God, will have wrestled with the issue of divine action in the world. The beatific vision remains in the same register, since creatures, although in the presence of God and thus no longer strictly speaking in the world, remain creatures and finite. Thus, this paper serves as a kind of prolegomena to the treatment of the two themes of the volume. It prepares the ground of discussing the changes a human person undergoes in justification, by clarifying what it can mean for God to produce those changes.

The present paper relates to the first two sets of difficulties of an account of divine action in the world. In the history of Christian theology two broad traditions have emerged, which conceptualize this God-world relation differently. These result in two different conceptions of divine agency. I will define a 'conception of divine agency' as an account of what it means for God to act, a definition of divine action.

Western theologians, under the influence of Augustine and Aquinas in particular, have settled on a conception of divine agency that understands a divine action as the 'production of created effects' (Augustine 1991: I.2.70). For this tradition, the fact that God acts simply means that he is responsible, in a certain special way, for the existence of certain created realities, which are thus effects of his efficient causality. No further explanation is given of the way in which God produces these realities, beyond an appeal to divine omnipotence and sovereignty. The key point, though, is that to encounter God acting in the world simply is to encounter 'created effects' of his power.

The Eastern church, on the other hand, has evolved a very different account of divine agency, especially in the wake of Gregory Palamas, through an appeal to the notion of God's 'uncreated energies'. God's activity in the world is parsed as more than just the bringing about of created effects. It is a kind of extension from God to the world, such that to encounter God in the world is to encounter his uncreated and natural energies.

My aim here is to make a modest defense of the Western model of divine action as the production of created effects. Given the dependence of these models of divine agency on many other broader paradigmatic commitments, it is difficult to defend a single doctrine in isolation from a consideration of the broader framework as a whole. Behind the two traditions stand two very different metaphysical constructions. Hence the modesty of my defense: I will restrict myself to responding to objections formulated against 
the Western model, while raising some critical questions about the Eastern account. I will seek to show the intelligibility and defensibility of the Western model in its own terms, by suggesting that there are adequate resources within this tradition to respond to some of the most important concerns voiced from the East. That is in terms of defense. In terms of offense, I will be suggesting that the notion of 'created effects' is fecund from a trinitarian standpoint, namely, it is a model that expresses both the unity of nature and the diversity of persons in divine action.

The Eastern tradition has formulated two essential challenges to the Western model. First, the East fears that the language of 'created effects' makes it difficult to understand how deification is possible. If all we encounter are the created effects of God, how may we become 'partakers of the divine nature?' (2 Peter 1:4, ESV). A second objection focuses on the Western understanding of the simplicity and pure actuality of God. It is alleged that such a conception, which grounds a conception of divine agency, results in a God who is ultimately neither free nor responsive to creation.

From these objections it is clear that this debate could be broken up in two distinct conversations. The first is a debate about the divine nature and attributes. The second, which largely results from the first, is a debate about divine agency specifically. This observation gives us the structure for this paper. The first section will assess the differences between the two understandings of the divine nature and attributes. I will address both the differences in trinitarian doctrine, and the attending differences in their understanding of the divine attributes. The notion of uncreated energies will also be introduced at this level, since for the Eastern tradition, the energies belong to the very nature of God. The second section will address specifically the different theologies of divine action and their implications. I will ask three questions: what is a divine action? How are the trinitarian persons involved in the divine actions? What do these actions imply about divine simplicity? The final section will be making some constructive claims that demonstrate what I am calling the 'fecundity' of this model of divine agency.

\section{Nature, Persons, Energies}

It is a common place that the two traditions have moved on different tracks of Trinitarian doctrine. Some attention to their differing constructions is a prerequisite for a proper understanding of the respective views on divine agency.

The West, Aquinas in particular, understands the divine persons to be 'subsistent relations' (Aquinas 1947: I.29.4). There is thus an equiprimordiality of persons and substance in God (Emery 2000). If we take persons as being concrete manifestations of an essence, and we wish to avoid either 
tritheism, or a fourth being over and above the persons, we arrive at the principle that God's essence is identical with his existence (Aquinas 1947: I.3.4). Thus it becomes a matter of necessity to define the persons in such a way that they remain coterminous with the divine essence. The notion of 'subsistent relations' aims to do precisely that: a person is a real relation, subsisting within the divine essence and constitutive of this divine essence.

These relations which define the persons are oppositional and at the level of substance. For the Eastern Orthodox theologian Vladimir Lossky, this is characteristic of the Western approach, which, he claims, typically considers natures first and then proceeds to agents. There is a certain priority of the triune persons over their oppositional relations, which Lossky wants to preserve. The relations between the persons 'only serve to express the hypostatic diversity of the three; they are not the basis for it. It is the absolute diversity of the three hypostases which determines their differing relations to one another, not vice versa' (Lossky 1974: 79).

The claim, dear to the East, that neither the persons, nor the substance, should be identified with their operations is fundamental. Operations and relations are those which flow from the ultimately incomprehensible 'selves' which are the persons. The latter must not be collapsed into their operations. Nevertheless, the persons must not be construed as operation-less. That would render them mere abstractions. Palamas resolutely drives home this point (Palamas 1988: ch. 136). We know God as personal precisely through his energies (to be defined momentarily). Yet these energies must flow from a personal center that is ultimately ineffable and not confused with his operations.

So on the one hand, the persons must be distinguished from the divine essence and not reduced to relations within the substance; on the other hand, there must also be a distinction between the persons and essence, on the one hand, and the operations, or energies on the other. But these must be 'real distinctions' within God, and not simply formal ones. That these are 'real distinctions' is essential for the preservation of the utter ineffability and unparticipability of God. So what are these 'energies' if they are distinct from God, yet natural to him?

Lossky defines the energies as natural manifestations of the essence of God, yet external to the very being of the Trinity (Lossky 1974: 81). Energies are 'outpourings of the divine nature which cannot set bounds to itself, for God is more than essence. The energies might be described as that mode of existence of the Trinity which is outside of its inaccessible essence. God thus exists both in his essence and outside of His essence' (Lossky 1974: 73).

Note the importance of the real distinction. The three-personal God must not be confounded with his operations, including those operations 
that do not terminate into a created effect: 'For Orthodox thought, the energies signify an exterior manifestation of the Trinity which cannot be interiorized, introduced, as it were, within the divine being, as its natural determination' (Lossky 1974: 80). Thus the energies are natural manifestations of the essence, yet external to it. Or, as Dumitru Staniloae puts it, 'as dynamic manifestation', they are 'around his being and are not identical with his being itself' (Staniloae 1994: 126).

It is precisely the 'real distinction' that enables the concept of uncreated energies to do its dogmatic work. The energies mediate between the world and God, while preserving the distinction between the two and the divine transcendence. As Lossky writes 'If we were able at a given moment to be united to the very essence of God and to participate in it even in the very least degree, we should not at that moment be what we are. We should be God by nature' (Lossky 1974: 70).

Without the energies, deification would be impossible, for either we would be identified with God (if God's essence is identical to his operations), or we would only be encountering created effects (if his operations are understood as mere created effects). God's operations are nothing other than God himself, yet not the very essence of God. This is the cash value of the real distinction between essence and energies. As Staniloae explains: 'The operations, therefore, are nothing other than the attributes of God in motion, or God himself, the simple one...' He goes on to say, 'God himself is in each of these operations or energies, simultaneously whole, active and beyond operation and movement. Thus his operations are what makes God's qualities visible in creatures, creating these with qualities analogous, but infinitely inferior, to God himself, and then imparting his uncreated operations or energies to them in higher and higher degrees' (Staniloae 1994: 126).

I will rehearse the difference between the two paradigms at this point. For Western theology, God is pure act, namely an identity of essence and existence. He is identical with his operations. But his operations in the world take the form of created effects (more on this later). The East, on the other hand, operates a 'real distinction' between God's persons, essence, and energies. God is not identical with his energies, which nevertheless naturally flow from him. These energies nevertheless permeate creation, ultimately deifying it, allegedly without compromising divine transcendence.

The Western theology of pure act, the identification of God with his operations is taken by the East to inevitably imply the necessity of creation and thus it represents an attack upon the divine freedom. If God is identical with his operations, and if among these operations we observe the activity of creation, and furthermore, since God is a necessary being, it must follow that creation itself is necessary. This would compromise the ontological dis- 
tinction between God and the world and it inevitably seems to lead, so many Eastern theologians think, to a pantheistic worldview. From the perspective of the West, on the other hand, this 'real distinction' between essence and energies seems to compromise divine simplicity. We must dwell for a while on this debate.

Lossky articulates the hesitation about the Western construction of divine simplicity, as an identity between essence and existence, or the parallel notion of pure act. He argues that if we deny the real distinction between the essence and energy, we cannot fix any clear borderline between the procession of the divine persons and the creation of the world; both the one and the other will be equally acts of the divine nature' (Lossky 1974: 73). This is a powerful objection indeed: if God is pure act and in God there exists no potentiality, but only actuality, then the creation of the world is not an actualized potentiality in God. So there does not seem to be any clear distinction between the operations by which the persons are distinguished and the operations by which creation is made.

Lossky also suggests that the real distinction between energies and essence is found, though with less doctrinal precision [than in Palamas] in most of the Greek Fathers. [...] It is in fact an integral part of the tradition of the Eastern church, and is closely bound up with the dogma of the Trinity' (Lossky 1974: 71). This latter point is not without importance. It appears that the Eastern church had already taken its own path on the matter of divine simplicity from the time of the Cappadocians, who are opposing Eunomius who had also conflated God's essence and his attributes. In response, the Cappadocians speak about God as 'superessential', a tradition carried over faithfully in the East.

Palamas' own theological construction is motivated by his opposition to Barlaam, whom he takes to hold that 'God is substance alone, with nothing observed in him' (Palamas 1988: ch. 134). To this Palamas invokes standard trinitarian doctrine by reminding Barlaam that God must also possess relation and therefore there must be something more than substance in God.

So a first deflection of the charge that simplicity is sacrificed seems to turn on the claim that the doctrine of simplicity already must be consistent with some real distinctions in God, at the very least the distinction between essence and persons, or relations. Moreover, this distinction is the reason why we can experience God as personal. As Palamas argues, 'if the substance does not possess an energy distinct from itself it will be completely without actual subsistence and will only be a concept in the mind' (Palamas 1988: ch. 136). This is how we know God to be personal, or 'to possess individual subsistence' (Palamas 1988: ch. 137). Unless we are able to make this distinction, Palamas continues, we cannot relate to God as one who acts freely. He believes Western doctrines of simplicity are guilty of Sabellius' 
impiety: 'If these things [nature and energy] are in no way different, God possesses no capacity for creation and operation' (Palamas 1988: ch. 142), since this capacity must not be identical with his nature, which would imply the necessity of creation.

But surely, the West has good reasons for their doctrine of simplicity, chief among which has to do with the divine immutability. While it has always insisted on the contingency of creation, as well as its temporality, it tried to do so without suggesting that there are accidents in God, i.e., a move from potentiality to actuality. God must not be understood to change, for that would imply imperfections.

Now the East relegates mutability to the divine energies, while insisting that God in his essence remains simple and immutable. So Staniloae: 'God himself changes for our sake in his operations, remaining simple as the source of these operations and being wholly present in each of them' (Staniloae 1994: 126). He further argues that there are continuously new operations and energies: 'These acts neither enrich nor change God himself for he is above all his acts and above all the divine attributes which he manifests through them' (Staniloae 1994: 128).

The idea of God's transcending his very energies is also affirmed by Palamas: 'since God is entirely present in each of the divine energies, we name Him from each of them, although it is clear that He transcends all of them. For given the multitude of divine energies, how could God subsist entirely in each without any division at all? And how could each provide him with a name and manifest him entirely, thanks to the indivisible and supernatural simplicity, if He did not transcend all these energies?' (Palamas 1983: 57). To the additional challenge that the distinction between essence and energies introduces composition in God, Palamas responds that an energy is 'not a substance for it is not one of those things that can subsist on its own' (Palamas 1988: ch. 135).

The Eastern challenge of the Western understanding of simplicity, then, could be summarized in the following way. To render God as pure act, meaning that God is to be identified with his attributes and with his operations, appears to imply that creation, and in fact any action of God, is a necessary emanation from his nature. Moreover, it is difficult to understand how creation could personally relate to such a God, since in him there can be no accidents. A God who is pure act cannot modulate his actions in response to historical activity.

Thus, the power of the real distinction between essence and energies resides in its ability to account for a real and personal encounter between humanity and God in deification, which does not compromise divine transcendence. It also accommodates the reality of God's changing operations as responses and interactions with his creatures. 


\section{Trinitarian Agency}

I have explained how the distinction between essence and energies is dogmatically grounded in an understanding of the Triune God according to which a person is prior to its relations. God remains simple, yet his superessence is not identical with his actions. Rather, his actions flow from his essence and are transcended by it. On the other hand, in the West, Trinitarian persons are precisely relations within the unity of the substance; they are subsistent relations. Moreover, the divine essence or substance is the divine existence, pure actuality. Consequently, everything that God can do he already has done in the fullness of his being. This brings us to the question of just what a divine action is. It is not surprising to see different conceptions of agency flowing from these alternative models of the divine nature and persons. This section unpacks these different conceptions of agency.

As we saw, from Augustine onwards, Western Trinitarian theology understands a divine action as the production of certain temporal and created effects. According to the divine simplicity, it is impossible for God to enter into composition with anything. Therefore, any action that God must undertake, he will undertake without any passive potency. From this follows the famous and much misunderstood principle, that the relation between God and creatures is real in creatures, but not real in God (Aquinas 1952: 4.4-5). By this nothing else is meant than the idea that God enters into the causes of creatures, as efficient cause, without creatures, as effects, determining the divine cause at all.

Consequently, there can be no thought of God becoming the form of any being. In Book One of the Summa Contra Gentiles, Aquinas argues that God is not the form of any body. He writes that 'the divine being cannot belong to any quiddity that is not being itself' (Aquinas 2009: 1.27.2) and adduces a number of arguments in support of this. One of these is an argument from composition: 'the union of form and matter results in a composite, which is a whole with respect to the matter and the form. But the parts are in potency in relation to the whole. In God, however, there is no potentiality. Therefore, God cannot be a form united to some thing' (Aquinas 2009: 1.27.4; cf. Aquinas 1947: I.3.8).

This denial of composition in God is directly related to our discussion. The question for us is the status of the realities with which we come in contact when we encounter a divine action in the world. For Aquinas, divine simplicity stipulates that any such relations between God and something which is not God can only take the form of efficient (and final) causality. God may not be the form of anything. 
Now remember that Staniloae had described the uncreated energies as being in motion, and divine at the same time. Lossky had also described them as an existence of God outside of God's own nature. For the West, this smacks precisely of the kind of composition that Aquinas would want to deny. To him, such an intermediary notion would appear to mingle God with other things. This is a 'manifest untruth; since it is not possible for God to enter into the composition of anything, either as a formal or a material principle'. (Aquinas 1947: I.3.8). God can be in other things only as efficient cause. In insisting on this Aquinas is well aware that he is pushing against a certain interpretation of Dyonisius (Aquinas 2009: 1.26), but also against Augustine's own idea of God as the world-soul (Aquinas 1947: I.3.8).

In contrast to this, the Eastern fathers are searching for a conceptual intermediary between the idea that divine actions are accidents, and the idea that they are mere created effects. Palamas, for instance, insists that while the effects of the divine energies are creatures, the energy itself cannot be in the category of creatures. Lossky concurs: 'Even if creatures did not exist, God would nonetheless manifest Himself beyond His essence, just as the rays of the sun would shine out from the solar disk whether or not there were any beings capable of receiving their light' (Lossky 1974: 73). This seems to introduce a category between an action which entails the production of something outside the cause, as efficient causation, and an action that has no termination outside of the essence itself. David Bradshaw helpfully clarifies the distinction between two Aristotelian notions, kinesis and energeia, or between motion and energy (Bradshaw 2004: 7). A motion is an activity that has a termination and which is not an end, but is for the sake of some end. Moreover, it is an activity that is complete when it achieves what it aims at. It also 'has parts which are different in kind from one another and from the whole' (Bradshaw 2004: 10). On the other hand, energeia, whose paradigmatic case is sight, has no termination; is an end in itself; is 'complete at any moment because it does not lack anything which coming into being later will complete its form;' is homogenous, as opposed to composed of parts (Bradshaw 2004: 10).

So the energies are the life which emanates from God's triune being, quite apart from creation. It is these natural 'rays' which produce and sustain creation. The energies are thus the link between the essence of God and the created realities which they sustain, as Staniloae writes: 'although God effects something on each occasion through a particular operation, yet he is wholly within each operation. On the other hand, through each operation God produces or sustains a certain aspect of reality; consequently this aspect of reality has its cause in something corresponding to it, though in an incomprehensible way, within God himself' (Staniloae 1994: 125). 
The energies are not to be confounded with the persons, or with the divine essence. They emanate from it, insofar as the persons are more than just substantial or subsistent relations. And so there is no pressure to ascribe immutability to the operations themselves: 'God himself changes for our sake in his operations, remaining simple as the source of these operations and being wholly present in each one of them' (Staniloae 1994: 126). God may produce 'continually new acts' (Staniloae 1994: 128), and he may indeed be acting differently in different dispensations. Yet Orthodoxy insists that 'These acts neither enrich nor change God himself, for he is above all his acts and above all the divine attributes which he manifests through them' (Staniloae 1994: 128).

\section{The Common Energy of the Triune Persons}

One question which has emerged as a supposed difficulty for the Orthodox tradition is the particular manifestation of the triune persons through the energies. The introduction of a third 'dimension' (for lack of a better word) between the essence/persons and the created world raises the issue about the manner in which the distinct divine persons are related to the uncreated energies.

Both traditions would insist that actions pertain to persons. Aquinas writes that 'each thing acts according as it is in act' (Aquinas 2009: 1.29.2; cf. Aquinas 1952: 20.1.arg.2). Staniloae concurs: 'inasmuch as the essence is only really given in a subject, or hypostasis, it could be said that what supports all the attributes of God, in which creatures participate, or the very support of existence itself, is the hypostatic reality or the threefold divine hypostatic reality' (Staniloae 1994: 129).

However, since the persons constitute a single being, there is both a single energy, as well as multiple energies. There is a single energy in the sense explained by Palamas: 'The Father and the Son, together with the Holy Spirit, in their relation to creation constitute one principle, one master, one Creator, one God and Father, provider, ruler... etc' (Palamas 1988: ch. 132). This means that there is only 'one energy of the three divine hypostases not in the sense of similarity as in our case, but in the sense of truly one even in number' (Palamas, 1988: ch. 138).

This principle is basically identical to the so-called doctrine of inseparable operations as it was developed in the West. This is a remarkable point of convergence of the two accounts of divine agency, despite their divergence on just what the divine action represents. Lossky confirms this tradition: 'it is not even possible to attribute any particular energy to any one of the divine hypostases exclusively' (Lossky 1974: 79). Moreover, Lossky points out, 'In the order of the economic manifestation of the Trinity in the world, all energy originates with the Father, being communicated by the Son in the 
Holy Spirit'. And thus 'in their operation in the world, the consubstantial persons of the Son and the Spirit do not manifest themselves-for they do not act in virtue of some will of their own-but the Son makes known the Father and the Holy Spirit bears witness to the Son' (Lossky 1974: 82).

This is consistent with the principle that we know the persons from their energies. But how is the order of the processions reflected in the economic dispensation? In this case, it does not seem to follow the same order, since the Spirit proceeds from the Father alone, yet it bears witness to the Son, and not to the Father.

Lossky's response to this point is that the order of the processions need not be respected in the order of the missions, as the West insists. This would amount to 'Confounding the exterior aspect of God's manifesting activity in the world $[\ldots]$ and the interior aspect of the Trinity' (Lossky 1974: 85). However, if the missions do not reveal and extend the processions, and if the divine energies are common to the triune persons, it becomes difficult to understand how the divine persons might be individuated economically for the sake of our knowledge and contemplation.

We have arrived at an impasse which is somewhat similar to the Western one. Catherine M. LaCugna, a critic of the Western doctrine of inseparable operations, suggests that the Eastern account 'sounds suspiciously similar to Augustine and to Thomas Aquinas' (LaCugna 1993: 194). She argues that 'This is the primary weakness of Palamite theology: despite the strong theology of grace, the creature cannot have immediate contact with a divine person, only with a person expressed through an energy' (LaCugna 1993: 186). But since these energies are not differentiated among the persons, such that no person has its own unique economic energy, we do seem indeed to be at an impasse.

Let us summarize our findings so far with respect to the two conceptions of personal agency. The Western account assumes the concept of divine simplicity, which rejects all composition in God. As such, no other reality is divine, i.e., can have God as its form (since the divine nature is not multiple, but single and identical with its concrete existence). For this reason, it would be suspicious to speak of the energies as divine, since it would mean to call divine something which is neither essence nor persons. God's operations do not have a distinct ontological status, but are identical with Himself. When these operations terminate in the temporal world, they are recognized and defined as the production of created effects in the world. The way in which God is a cause of created effects must not compromise his absolute simplicity. He is in the world, and in anything which is not God as a cause is present in its effects, i.e., through his efficient causality.

For the East, on the other hand, the divine actions must be God himself extending all the way into creation. The notion of uncreated energies rep- 
resents an extension of God that does not compromise divine aseity and simplicity, but which makes it possible to speak of God as changing and interacting with creation, without compromise to the ineffable divine substance, or persons.

The remainder of the paper will try to accomplish two things. First, to show that the Western tradition contains resources to address the challenge to the doctrine of simplicity, namely that it sacrifices the freedom and responsiveness of God; second, that thinking about divine agency in terms of created effects makes possible an important distinction, between divine operations (which are inseparable and appropriated to the various divine persons), and divine missions, which are proper (not simply appropriated) to the persons and represent a true and unique communication of a particular person, in a certain form.

\section{Simplicity, Operations, and Missions}

Simplicity, Divine Freedom and Responsiveness

As I explained, the Eastern tradition expresses some significant hesitation about the Western construal of simplicity. By and large these hesitations are not unique to the Orthodox, but they echo some common modern reactions to simplicity within Western theology itself. While this does stem to a large extent from an abandonment of a certain metaphysical framework, the fact that they are also voiced from an Eastern perspective demonstrates that they are not simply idiosyncratic.

The reasons why simplicity seems suspect to the Eastern tradition can be boiled down to two points: a simple God of pure actuality cannot be free in relation to creation; second, a simple God of pure actuality cannot be thought as meaningfully relating to creation in the sense of being responsive to it. The creation of the world is the primary test case for this. The East has long suspected that the Western doctrine of God, especially in its Thomistic version, ineluctably leads to pantheism, which is a confusion of God and the world. The suspicion has also been that it requires that the creation is necessary, since God has always been creator-there being no potentiality in God.

The East asserts that God eternally possesses the power to create, yet this is not eternally actualized. As we have seen, the energies can be thought of as co-eternal powers of God, quite apart from this power having an external terminus. Lossky insists that God's will creates the world, not the energies, yet through the energies (Lossky 1975: 88-90). Thus the energies are powers that are in the essence, or, in Staniloae's words, around the essence, yet not identical with the essence itself. Palamas also treats the energies as powers. Not only the essence is eternal, but the powers are also. If only the essence were eternal, the powers of creation would have to be acquired. Palamas' solution is to say that the powers are also eternal, although distinct 
from the essence. He argues that 'they exist in the divine essence as do the powers of the senses in what is called the common spiritual sense of the soul' (Palamas 1983: 93).

For Palamas, to say that God is without energy amounts to denying the existence of God. He believes this is what Barlaam is doing when he suggests that only the essence of God is uncreated and eternal, while God's works are created. 'What impiety!' Palamas exclaims, 'It follows from this that God has no natural and essential energies. This amounts to openly denying the existence of God [...] for no nature can exist or be known, unless it possesses an essential energy' (Palamas 1983: 104).

For Palamas, Staniloae, and Lossky, the divine energies are the vital life of God. Without energies, God is a simple abstraction. Yet the divine energies are distinct from God, since they represent that which is participable in Him. Papanikolaou sums up the Eastern solution: 'The activities of God make God knowable, but only if such activities are fully God. Yet at the same time, such activities do not make creation divine since there are degrees of participation in the energies of God' (Papanikolaou 2003: 363). For these authors, one can only preserve both the divine freedom as well as the reality of participation in Him if there distinction between essence and energies holds and if divine simplicity is taken to mean that God ultimately transcends his energies.

Neither can a God of pure actuality be responsive to his creatures. On an essence-energies framework, however, 'God in himself, who is above time, meets with the creatures in time through his energies' (Staniloae 1994: 150). This entails that eternity cannot mean timelessness and immutability, as the same Staniloae argues: 'Eternity cannot be the quality of an immutable substance' (Staniloae 1994: 150). The Romanian theologian comes close to a Hegelian position on eternity, even if he explicitly denies it (Staniloae 1994: 151): 'In relation to us the eternal God is placed in a position of expectant waiting... Eternity accepts time within itself' (Staniloae 1994: 158). But this divine temporality obtains on the plane of the energies: 'on this road of ours toward eternity, God himself experiences together with us the expectant waiting (and hence time) on the plane of his energies and of his relations with us' (Staniloae 1994: 159).

There have been plenty of responses to the two objections. Going over that ground would be redundant. But there is another point that does bear discussion. That is, the East does not abandon simplicity, but shifts it to another, super-essential level. The question is whether this relocation of simplicity is defensible. More specifically, does it hold water in terms of its conception of agency?

Let's rehearse the model of divine agency. God is super-essential, in the sense that he is above his own attributes. His attributes flow from him, but 
are ultimately transcended by him. His operations, likewise, also flow from his super-essential being. But his energies are eternal, without their temporal effects being eternal. His energies change and modulate, sometimes in response to historical realities, but these changes are not changes in the essence of God.

The key question has to do with the joint between the tri-personal essence of God and his energies. The insistence that his energies change, yet without his essence changing raises the question of the manner of the derivation of the energies from the essence (cf. Williams 199: 38). Either the energies are grounded in some way in the essence, or they are not. Since the second option is utterly unacceptable-since it would imply that the energies are not divine-the question is, in what way are they grounded in the essence? Whatever the energies are grounded in, whether the divine will (to highlight the divine freedom), or in something else, there must be some sort of correlate to the economic change in the immanent Trinity. The typical suggestion, as we have seen, is to say the divine will. But does a change in the energies also entail a change in the divine will? If so, can simplicity still be claimed to obtain at the level of the essence, if there is a correlate to an energetic change?

One response would be to say that the divine will, or whatever else the energies are grounded in, is beyond change. So it would be an improper projection to distinguish between one act of will, resulting in a certain modulation of the energies, and another act of will, resulting in another modulation of the energies. In that case, we would be restricted with a mere stipulation: it is merely affirmed that changes in the energies are grounded in the will of God, but theological reason refuses to tread further. Theological modesty is always praiseworthy, but one still has to wonder whether much is achieved by relocating simplicity to a level that is utterly indescribable. Moreover, the Western suspicion is that if it is left so utterly indescribable, one has to wonder if anything has been revealed at all? If we have no basis for the changing and modulating energies of God, except a statement that they are anchored in a will that is transcendent and simple, despite its apparent mutations, how can these energies be said to reveal anything at all about God?

I have not said anything to respond to the significant objections to simplicity in general, nor is that my aim. But it is doubtful that the retention of simplicity at another level really achieves much beyond moving the pressure-point higher up the ontological ladder-indeed, perhaps at a level where the worry can never be addressed. In other words, if the objections usually raised against simplicity are valid, they are fatal whether or not we push it to the super-essential level. 
Western simplicity encompasses God's essence, existence, and attributes. Everything about God is pure actuality. Eastern simplicity applies strictly to the super-essential and tri-personal being of God, out of which radiate his energies. These energies touch the world in manifold and changing ways. The changing energies are not simply a function of creation (as in the West, although much care needs to be exercised when this is affirmed), but they are anchored in God's own will. The advantage is that God retains his freedom in relation to creation, willing to energize in this or that way. But the manifest difficulty of this position is that it leaves the notion of a divine will, or whatever we may call that which moves the energies, which is simultaneously changing and beyond change mysterious and inscrutable. This can only have the consequence of stoking anxiety about divine constancy and character. The difficulty is that the changing energies need to be anchored in something that is nonetheless beyond change. But that in which they are anchored must be immutable and simple, yet free (given their objection to Western simplicity).

Therefore, the sorts of problems that the concept of simplicity has cannot be resolved through a real distinction alone, but only by either severing the link between essence and energies, or making it utterly ineffable, which is no gain over the West, since the latter could always claim the same ineffability as a solution.

\section{Operations and Missions}

The foregoing does not imply that Western accounts of simplicity are successful at responding to the twin objections. But we have sufficient reason to doubt that the relocation of simplicity at a super-essential level represents a solution to the worry.

I now wish to show that the Western model of agency as the production of 'created effects' is theologically fecund in that it enables an important distinction between operations and missions. Remember that the Eastern critique of 'created effects' has been that it does not allow for an encounter with God himself, but only with created, albeit supernatural realities. But such an encounter cannot be a means to deification, since it would not amount to participation in God himself. If, on the other hand, we allow for a real distinction between essence and energies then we can have an appropriate participation in God that would not threaten divine transcendence or essential incomprehensibility.

The difficulty with the Eastern proposal, I explained, has to do with its apparent obfuscation of the triune persons. Not only are the energies common to the persons, to the exclusion of unique personal operations, but their order is also not representative of their processions. It follows that this account promises a real participation in God, yet the hypostatic reality of 
the persons remains unparticipable. We do not seem, after all, to receive a self-communication of God if God's personal reality remains indistinguishable.

Certainly, the Western model has been thought to be similarly deficient, since it also affirms the principle of inseparable operations. But there is a fecundity to its concept of created effects that is not immediately appreciated. It is true that the doctrine of inseparable operations affirms that every action of God ad extra is inseparably the self-same action of the Father, Son, and Holy Spirit, and that neither of these persons has an economic operation that is unique to them. But the West also distinguishes between the divine operations, which are inseparable and at most appropriated to one of the persons (cf. Augustine 1991: bk. IV; Aquinas 1947: I.39.7-8), and the divine missions, which are unique to the divine persons.

While a divine operation is the production of an effect in the world, a divine mission represents the extension of a procession to include a created and temporal effect. The mission of the Son, therefore, represents the extension of his procession, that is to say his hypostatic reality, to include the human nature of Jesus Christ. The mission of the Spirit likewise refers to the extension of the life of the Spirit to include created effects. Now these missions take up created realities into a form of union with the divine persons. Yet these unions do not change or affect the divine persons themselves, which remain simple and immutable. It is the created realities which are transformed and indeed, in some cases one may say, deified in the process. The union between the divine persons and these realities leaves the persons intact. But it is precisely because of the union, say, between the Logos and the human nature of Christ, that we can say we have a divine self-communication, a revelation of the second person of the Trinity.

In the concept of missions it is possible to affirm a real participation in the being of God, based on the triune self-communication, precisely because in a mission the processions are extended into creation, without change. How is this possible? How is the 'extension of a procession' less problematic than the notion of an energy whereby God lives outside of Godself? The key difference is that in the case of a mission, the created reality assumed into union with one of the proceeding persons is not taken up into the cause. That is, the Logos is not the formal cause of the human nature of Jesus Christ. On the other hand, the notion of an uncreated energy sounds more like a real extension of God. And thus in the incarnation, the human nature of Jesus Christ is not simply deified by the common energies of the Trinity-although that certainly remains true-but is also united specifically with the second Person. And so we have the revelation of the Logos, not because something like an ontological intermediary connects the two ontological 
planes, the created and the uncreated one. There is no need for such bridging, since God is already omnipresent.

The notion of divine omnipresence plays an important part in a theology of the divine missions. The West has not shared the Eastern anxiety about divine presence, and thus 'created effects' were never thought as buffering it. Rather, the West tends to think about different types of divine presence. God is intimately present in creation in virtue of his efficient causality. This is the divine omnipresence. But in a divine mission, whether visible or invisible, the presence of God is intensified in such a way that creatures come to operationally resemble God. In a divine mission, a creature to which God is already present in virtue of his immensity, comes to be united to one of the persons of the Trinity. Through certain 'created effects', which may also be called gifts-faith and love-the whole Trinity comes to dwell in the believer (John 14:23). Far from making God's action either impersonal, or buffered, these created effects are precisely the form through which God draws creation to himself, and thus the formality of a divine mission, in which a proper relation with a divine person is realized.

These notions require explanations that are beyond the scope of this paper. As I noted, the competing models of agency can only be discussed as part of the broader theological paradigm. Any analysis such as the one attempted here can only be rather limited in scope. What I hope to have shown is that the Western model of triune agency, though not without difficulties, has a demonstrated fecundity especially in relation to Eastern desiderata: divine participation, revelation, and preservation of divine simplicity and aseity.

\section{Conclusion}

It has emerged in the course of this study that the Eastern Orthodox tradition does not wish to abandon divine simplicity, but chooses to relegate it to an ineffable domain, transcending the divine operations ad extra. However, this relegation of the simple divine being to ineffability raises the fear of a return to a Deus absconditus, since we have no way of connecting his revelation to the innermost dynamism of his being.

This is precisely what is at stake in the Eastern refusal to trace the missions of the divine persons to the eternal processions. This hesitation stems from the thought that such an extension of a procession would result in an absurd mingling of the divine persons with the other created effects, or other human persons for that matter, to which it would be united. This fear is misplaced, but also the result of an assumption that a participation in a divine hypostasis would result in the explosion of the Trinity into a myriad hypostases. The only alternative, then, is to think of participation through the energies. 
The account of divine agency through the notion of 'created effects', however, has no reason to fear such a dissipation of the Trinity, because it understands participation in a person along the lines of a participation in the personal property of that hypostasis. In this case, the divine hypostasis becomes an exemplar cause, not a formal cause, of an indwelling. This is a real participation in distinct triune persons, and not just in their common energies. The manner in which such union and indwelling takes place, however, is conceived in such a way as to prevent any modification of God's actuality. Creatures are drawn to participate in the Trinity in the sense that they come to resemble the triune persons operationally, through knowledge and love. The Son, as God's self-knowledge, becomes the exemplar for our knowledge of God; the Spirit as the love between the Father and Son, becomes the exemplar for our love of God.

This yields an account of deification that is more attentive to the personal distinctions within the Trinity. Deification, in this case, is not participation in a generically One God, but a participation in the life of the Trinity, as it flows from the Father, to the Son, and to the Holy Spirit. Even though the external operation of the Trinity is indivisible, through the created effects that are produced, human persons are drawn into union with the distinct persons. This personal union to Father, Son, and Spirit respects both their unity as One God, as well as human creaturehood. The latter is the case since the formality of the union with a distinct person is not the person itself, but a created effect, a gift, whereby we become united to that person. The gifts draw us into the triune life even though they are created.

The Eastern hesitations about the presence of God in creation make any such participation in the persons problematic-and resulting in myriads of sons. For the West, participation does not entail the annulment of our created status, but an uplifting of our operations to the point where we come to resemble the divine persons.

The indwelling of the divine persons is not simply appropriated, but proper to each divine person. However, it takes place through the formality of the created effects which are the common production of the One Trinity. So, for example, through love, which is the common production, as created effect, of the whole Trinity, we come to share in the personal property of the Spirit. Through faith, which is the common production of the whole Trinity, we come to share in the personal property of the Logos.

\section{Bibliography}

Aquinas T (1952) Questiones Disputatae De Veritate. On Truth 9. Mulligan R, SJ

(trans) Robert Chicago, IL: Henry Regnery Company.

Aquinas T (1947) Summa theologica. New York: Benziger. 
Aquinas T (2009) Summa contra gentiles. Notre Dame, IN: University of Notre Dame Press.

Augustine (1991) The Trinity. Hill E, OP (ed) Rotelle J O.S.A (trans) Hyde Park, NY: New City Press.

Bradshaw D (2004) Aristotle East and West. Cambridge: Cambridge University Press.

Emery G (2000) Essentialism or Personalism in the Treatise on God in Saint Thomas Aquinas. The Thomist 64(4): 521-563.

LaCugna C (1993) God for us: The Trinity and Christian Life. San Francisco: HarperCollins.

Lossky V (1974) The mystical theology of the Eastern Church. Yonkers, NY: St. Vladimir's Seminary Press.

Palamas G (1983) The triads. New York, NY: Paulist Press.

Palamas G (1988) The One hundred and fifty chapters. Toronto: Pontifical Institute of Mediaeval Studies.

Papanikolaou A (2003) Divine Energies or Divine Personhood: Vladimir Lossky and John Zizioulas on conceiving the transcendent and immanent God. Modern Theology 19(3): 357-385.

Stanniloae D (1994) The experience of God. Brookline, MA: Holy Cross Orthodox Press.

Williams A (1999) The Ground of Union: Deification in Aquinas and Palamas. New York, NY: Oxford University Press. 